\title{
LANGUAGE AND CHARACTER IN JANE AUSTEN'S EMMA
}

\section{BRUNILDA REICHMANN LEMOS}

Graham Hough in his essay "Narrative and Dialogue in Jane Austen" distinguishes five kinds of discourse in Emma: the authoria, voice, objetive narrative, colored narrative, free indiect style, and direct speech or dialogue. He says that "lively raconieurs" like Jane Austen

have two main weapons - one is their own individual wit and insight, the other is the power of mimicking, of entering into another's being, of momentarily becoming another character. Jane Austen has both at her disposal, and uses both in continual interplay against a background of uncoloured objective narration.(1)

The playfulness with which Austen mimicks or assumes a character's personality momentarily (free indirect style), as also the power found in Austen's use of dialogue, is the expression of "an unconscious delight in virtuosity," says Hough.

Austen's characters are always distinguishable by their particular and peculiar speech, that is, their speech reflects aspects of their personality and station in life. In Pride and Prejudice, for example, Mary Bennett's mode of expression illustrates a character whose approach to life is artificial and bookish. Lydia Benne:t's language, on the other hand, reveals complete lack of restraint or control. Little rieeds to be said about Mr. Collins' way of expressing himself in metaphors, elaborated sentences, il'ogical reasoning, and didactic phraseology.

Characters in Emma, as in anv of Austenùs nove's are also dislinguished from one another by the way they express themselves. The narrative passages which precede a protagonist's dramatic introduction in the novel usually give information about a character, 
but only through Austen's use of free indirect speech followed by dialogue will we respectively come closer and then "see" the kind of person each one is.

Austen's method of introducing characters in Emma is very systematic. Take Harriet Smith, Jane Fairfax, and Mrs. Elton, for example. First they appear in narrative passages, their mode of expression is then imitated in free indirect speech, after which they are introduced dramatically, that is, they talk to or communicate with other people. This method indicates the narrator's progressive removal from the world of the novel in which the drama of her characters take place (2). Her presence is most felt in narrative passages; then, she moves away to play the ro'e of a certain character, assuming a peculiar way of expressing herself by the use of free indirect speech which captures and renders with fidelity the tone, the expressions, the distortions, or the idiosyncresies of the character being imitated. Finally she removes herself completely and allows the character to speak for himself and the reader to be an "eye-witness" in the drama. Like Browning when he tried to explain why he used dramatic monologue, Austen, in the dialogues, takes the reader to the window so he himself can observe how each character reveals his personality through his way of expressing himself.

It is acknowledged that afier Mrs. Elton makes her appearance in Emma, the negative aspects of Emma's personality are somehow redeemed. Besides admiring he: wit, intelligence, and intellectual vitality, her magnanimity and lack of pettiness and selfishness, after Mirs. Elton we become more accepting of Emma's faulty judgement, of her determination, and of her manipulation of other people.(3) Of course, we are ready to forgive Emma's faults because we cannot help admiring her, bu: also because Austen chosses to picture her faults in extremis in the character of Mrs. Elton. Therefore it seems evident that one of the importani functions of Mrs. Elton in the novel is to act as a foil to Emma. The same is true to a lesser degree, of Harriet Smith and Jane Fairfax. Bo:h of them also stand as foils to some aspects of Emma's pe:sonality, and an analysis of these characters' language will establish how each of them relates to Emma, the protagonist.

Harriet, as a minor character, predominates in the first half of the novel, Mrs. Elion in the second half. Jane Fairfax never predominates because we have more silences from her than uiterances. Yet there is significance in Jane Fairfax's reluctance to commit herself. Her evasions contrast with Emma's assurance and unconcein about 
committing herself by stating a conjecture as if it were $a_{1}$ fact.

Harriet is first introduced in narrative passages. Her personality is partially depicted by Austen's use of free indirect speech, in which the narrator plays the role of Harriet, and dialogue follows. Jane Fairfax and Mrs. Elton come into the fictional world of Emma following the same steps.

Emma, in her relationship with Harriet, is the superior, the figure of authority, the one who manipulates. Harriet is the child-like, submissive, ingenuous girl. Emma's reasons for manipulating Harriet are good, but her endeavor to "educate" Harriet never succeeds. Harriet never becomes "the heroine Emma, tries to make of her."(4) Harriet's language shows nonetheless that even though Emma is not successful with her plans, Harriet has by the end of the novel acquired a certain degree of articulation which she completely lacks at the beginning of the novel. The narrator tells us that Harriet "was not clever, but she had a sweet, docile, grateful disposition; was totally free from conceit; and only desiring to be guided by anyone she looked up to."(5) She also says that "Harriet had no penetration." (p. 16) These statements which imply judgment occur in a narrative passage. Soon after, we find some lines in inverted commas in the same narrative passage. We hear then, for the first time, what we suppose to be Harriet's voice:

"two parlours, two very good parlours indeed; onde of them quite as large as Mrs. Goddard's drawing-room; and of her having an upper maid who had lived five-andtwenty years with her; and of their having eight cows, two of them Alderneys, and one a little Welch cow, a very pretty little Welch cow, indeed; and of Mis. Martin's saying, as she was so fond of it, it should be called her cow; and of their having a very handsome summer-house in their garden, where some day next year they were all to drink tea: - a very handsome summer-house, large enough to hold a dozen people." (p. 16)

The first characteristic of this speech, setting aside its subject matter, is the run-on repetitious sentences, the child-like flow of Harriet-like na.rative: and of . . . , and of . . . , and of .... We become aware that the narrator's iudgment of Harriet reveals itself in the unvaried sentence structure present in her language. The second important characteristic in this passage is the repetition of "aesthetic" judgments (if we can call a "pretty little cow" an aesthetic judgment) followed by the word indeed. Austen plays a trick 
nonetheless in Harriet's last expression of "aesthetic" judgmente. When the narrator repeats: "a very handsome summer-house" we are already conditioned to inseit indeed. But there is no "indeed" in the passage.

The ingenuous docility in Harriet is so far only conjecture. When we actually see how she speaks, we realize that conjecture becomes well-founded judgment, and that Austen's use of free indirect style is completely in character. Harriet's language is mostly fragmentary, full of clichés and exclamatory expressions; her grammar is faulty, and her senience structure unvaried. When Emma asks her if Mr. Martin does nor read, Harriet answers

"Oh, yes! - that is, no - I do not know - but I believe he has read a good deal - but not what you wouls trink any thing of. He reads the Agricultural Reports and some other books, that lay in one of the window seats - but he reads all them to himself. But sometimes of an evening, before he went to cards, he would read something aloud out of the Elegant Ex:racts - very entertaining. And I know he has read the Vicar of Wakefield. He never read the Romance of the Forest, nor thes Children of the Abbey. He had never heard of such books before I mentioned them, but he is determined to get them now as soon as ever he can." (p. 17)

Note the fragmentary aspect of the beginning of her speech, the mistake in "all them to himself", the co'loquial: "someiimes of an evening" and the awkwardness of "them now as soon as ever he can."

Faulty grammar also occurs later when Harriet is talking abou: Mr. Martin. "Not that I trink Mr. Martin would ever marry any body but what had had some education . . . for they the Miss Mar. tins are quite as well educated as me." (p. 19)

lgnoring all the "Oh!'s" and "Ah's" and "l's" of Harriet's styie she delights in the use of exclamations with the word odd as its nucleous: "very odd" she says (p. 18), "so very odd" (pp. 20 and 119), "so odd" (p. 57), "very odd" (p. 231), "how very odd" (p. 278). (No more comments about lack of va:iety!) Oddly enough there is usually nothing odd in the situations Harriet thinks as odd. "He was four-and-twenty the 8th of last June, and my birth-day is the 23rd - just a fortnight and a day's difference! which is very odd!" (p. 18) What is odd about it? 
"And so, there she had set, without an idea of any thing in the world, full ten minutes, perhaps - when all of a sudden, who should come in - to be sure it was so very oddl - but they always dealt at Ford's - who should come in, but Elizabeth Martin and her broiherl - Dear Miss Woodhousel only think. I thought I should have fainted. I did not know what do do. I was sitting near the door - Elizabeth saw me directly; but he did nor; he was busy with the umbrella. I am sure she saw me, but she looked away directly, and took no notice; and they both went to quite the farther end of the shop; 1 was so miserable! I am sure I must have been as white as my gown. I could not go away know, because of the rain; but I did so wish myself any where in the world but there . . . " (p. 119)

This passage should be quoted in full not only because Harriet seems to be at least partially aware that her expression "so very odd" is meaninglesse in the context but also because it illustrates the run-on repetitious sentence structure we find in free indirect style. The passage goes on like this for more than half a page and Harriet uses the pronoun $I$ as the subject of more than 40 sentences. A case can be made that Harriet, in this occosion, is excited and tired, but the repetitious sentence structure cannot be taken as an excuse for being out of breath. Disturbance or pertubation reveals itself rather by fragmentation than by repetitious sentence structure. Harriet's sentences here are mostly complete. Since the beginning of the novel Harriet's language contains no connectives to give smoothriess to her style.

"Only think of our happening to meet himl - how very odd! It was quite a chance, he said, that he had not gone round by Randalls. He did not think we ever walked this road. He thought we walked towards Randalls most days. He has not been able to get the Romance of the Forest yet. He was so busy the last time he was at Kingston that he quite forgot it, but he goes aain tomorrow." (p. 20)

Her style here is very similar to the passage in which $I$ is the subject of all sentences and she is neither excited nor tired.

Later in the novel, after Harriet's first disillusion in love, her language seems to become more varied and flexible. She decides to 
burn, in front of Emma, litrle useless relics she considers iokens of love from Mr. Elton.

"It is my duty, and I am sure it is my wish," she continued, "to have no reserves with you on this subject. As I am happily quite an al:ered creature in one respect, it is very fit that you should have the satisfaction of knowing it. I do not want to say more than is necessary - I am too much ashamed of having given way as I have done, and I dare say you understand me." (p. 229)

Besides the awkwardness of " $\mathrm{l}$ am sure it is my wish" and the melodiamatic tone of this passage, Harriet's language shows smoothness and control; she is even capable of uttering a clause before her main sentence. But soon after she exclaims her peculiar "It is very odd" which becomes ironically revealing of Emma's unconscious attachment to $\mathrm{Mr}$. Knightley.

In direct contrast to Hariet's childilike, simple, faulty languag:, we have Emma's articula:e, correct, straight-forward speech. Her style, when she is talking to Harriet, is marked by assertive expressions which establish her superiority (and her awareness of it) in status and intellect to Harriet: "but I would have you" (p. 19), "I want to..." (p. 19), "I wish you . . ." (p. 19, "Do not you begin . . " (p. 10). Expressions such as these vanish from Emma's language after her plan to have Harriet married to Mr. Elton fails. She neither imposes her will so openly nor plays the role of en authoritarian figure whose judgment is flawless.

A more subtle contrast to Emma's assertion nonetheless is suggested by Jane Fairfax's cautious and evasive language. The narrator tells us that "wrapt up in a cloak of politeness, she Jane seemed determined the idea that Jane Fairfax does not want to compromise herseif. When Emma asks Jane if Frank Churchill, whom she had met at Weymouth, is handsome, the narrator becomes Jane momentarily and answers:

"She believed he was reckoned a very fine young man." "Was he agreeable?" - "He was generally thought so." "Did he appear a sensible yound man; a young man of information?" - "At a watering-place, or in a common London acquainiance, it was difficult to decide on such points. Manners were all that could be safely judged of. under a much longer knowledge than they had yet had of Mr. Churchill. She believed every body found his 
Of course, Emma could not forgive her. Jane's style, depicted by the narra:or, is too removed from Emma's usual openness and proximity. Jane's style here is at least twice removed from a simple negative or affirmative answer. Her answer is not "I believe he is" or "I believe he is not" but "I believe somebody else thought or found him so." Jane's caution can, though, be jusified by the precariousness of the situation, by her fear of revealing her engagement. We should also note that so far in the novel Jane has not spoken directly to us. But when she does, caution is still one of the predominant characteristics of her style. Answering to her aunt about Mr. Dixon she "affirms" that he was plain, but soon after, when Miss Bates checks Jane's most recent statement with what she has said. about Mr. Dixon before, she wrihdraws to safer ground.

"My dear, you said that Miss Campbell would not allow him to be plain, and that you youself - "Ohl as for me, my judgment is worth nothing. Where I have a, regard, I always think a person well-looking. But I gave what I believed the general opinion, when I called him plein." (p. 118)

Jane's style, when she is not asked to make judgmenis on other people, is marked by quiet assertion, correstness, and elegance. Sometimes we detect a tone of self-pity, quite distinct from Emma's self-deprecating tone. During Mr. Woodhouse's dinner-party, when Jane Faifax is talking with Mr. John Knightley, he mentions her morning walk and the conversation leads to Jane's remarks.

". . You have every body dearest to you always at hand, l, probably, never shall again; and theiefore till I have outlived all my affections, a, post-office. I think, must always have power to draw me out, in worse weather than to-day." (p. 199)

Many times we feel that Jane is on the brink of tears, some:imes because she pities herself, sometimes because she can never be assertive enough to undercut Mrs. Elton's insufferable inte:ference. Jane's quiet assertion is usually mixed with earnestness.

"Excuse me," said Jane earnestly, "I cannot by any means consent to such an arrangement, so needlessly troublesome to your servant. If the errand were not a 
pleasure to me, it could be done, as it always is when I am not here, by my grandmamma's." (p. 201)

Soon after, no longer being able to bear Mrs. Elton's insistence that someone should pick up Jane's lefters at the post-office, Jane's disturbance reaches such intensity that she steps out of character and uses a style very much like Mrs. Elton's. As a counterpoint to these "effusions," Mr. John Knighley's remarks are very reasonable and logical.

Jane looked as if she did not mean to be conque. red; but instead of answering, she began speaking again to Mr. John Knightley

"The post-office is a wonderful establishmentl" said she - "The regularity and dispatch of itl if one thinks of all that it has to do, and all that it does so well, it is really astonishing!

"It is certainly very well regulatea.

"So seldom that any negligence or blunder appears! So seldom that a letter, among the thousands that are constantly passing about the kingdom, is even carried wrong - and not one in a. million, I suppose, actually lost! And when one considers the variety of hands, and of bad hands too, that are to be deciphered, it increases the wonder

"The clerks grow expert from habit. - They must begin with some quickness of sight and hand, and exercise improves them. If you want any further explanation," continued he, smiling, "they are paid for it. That is the key to a great deal of capacity. The public pays and must be se:ved well." (p. 201)

Expressions such as wonderful, really astonishing, the wonder, use of parallelism, and the exclamatory tone of the passage are rheto. rical devices and diction used by Mrs. Elton.

Mrs. Elton's language is the most artificial and idiosyncratic of the three minor characters who stand as a foil to Emma. Like Harrier's, Mrs. Elton's style is exclamatory in tone, repetitious, intermingled with stereotyped expiessions like you know, I assure you, upon my wond, I do not scruple. Unlike Harriet's, Mrs. Elton's speech shows fondness for parenthetical clauses, for foreign expressions such as caro sposo, barouchelandau, beau, and for self-praise. 
Repetition in Mrs. Elton's speech serves a purpose quite distinct from repetition in Harriet's. The subtlety with which Austen uses the same rhetorical device to suggest two distinct traces in personality is rather amazing. Mrs. Elton's use of repetition could be compared to a moth's attraction for the light. As soon as she is dramatically introduced in the novel, in her visit to the grounds of Hartfield, Mrs. Elton is quite astonished by the similarity between the house in Hartfield and her sister's house in Maple Grove. A. discreet character, if such similarity did exist, would not take more than two sentences to express it. Mrs. Elton's "delight" cannot be expressed in less than half a page and in the midst of her circumlocution she has, from time to time, to mention the name Maple Grove to make sure her audience knows what she is praising. (see Emma, p. 184) Soon after, her mind becomes fascinated by barouche-landau. Her speech then circulates around it.

"My brother and sister have promised us a visit in the spring', or summer at farthest," continued Mrs. Elton; "and that will be our time for exploring. While they are with us, we shall explore a reat deal, I dare say. They will have their barouche-landau, of course, which holds four perfectly; and therefore, wi.hout saying any thing of our carriage, we should be able to explore the different beauties extremely well. They would hardly come in their chaise, I think at that season of the year. Indeed, when the time draws on, I shall decidedly recommend their bringing the barouche-landau; it will be so very much preferable. When people come into a beautiful country of this sort, you know, Miss Woodhouse, one naturally wishes then to see as much as possible; and Mr. Suckling is extremely fond of exploring. We explored to King's-Wes'on twice last summer, in that way most delightfully, just after their first having the barouche-landau. You have many parties of that kind here. I suppose, Miss Woodhouse, every summer?" (pp. 185-86)

This mode of expression becomes an illustration of Mrs. Elton's meed to define herself by external refrences. She does not define herself by her motivations or actions, but by relating herself to places or objects which represent the epitome of high social c'ass. It is delighiful to see how clearly Mrs. Elton rereals the shallowness of her character and how her speech demonstrates she is completely unaware of it. Who cannot fail to perceive the irony behind her insis- 
tence on exploring places when it has never occurred to her to "explore" herself. In her opinion, she is a woman "blessed with so many resource" that self-analysis is quite superfluous.

Mrs. Elton's speech also implies a closeness to people whom she has only recently met, which causes an awkward atmosphere. To Emma, of course, Mrs. Elton's attitude is insufferable. She refers to Mr. Knightley, whom she has just met, as" 'Knightley!' . . . 'Knightley himself!' Was not is lucky? For, not being within when he called the other day, I had never seen him befose. . . . 'My friend Knightley" . . . " (pp. 188-89) Later in the novel Msr. Elton calls Mr. Knightley a humorist when he criticizes her by parodying her own expressions or by undercutting her trivialities. (See Emma, pp. 241-243) Mrs. Elton, however, misses the point of Mrs. Knightley's criticism complete'y in her reluctance to look at herself.

Unlike Emma's siyle in her relationship with Harriet and the genuine concern for Harriel's growth revealed in it, Mrs. Elton, in her relationship with Jane Fairfax, is always "irfantilizing" Jane, that is, talking to her as if Jane were a seven-year-old girl unable to discern her situation in the world. Certainly Mrs. Elton does not want Jane to "waste" her "fragrance on the desert air" (p. 191), whatever that means.

"My dear Jane, what is this I hear? - Going to the post-office in the rain! - This must not be, I assure you. - You sad girl, how could you do such a thing? It is a sign I was not there to take care of you."

Jane very patiently assured her that she had not caught any cold.

"Oh! do not tell me. You really are a very sad girl, and do not know how to take care of yourself. To the post-office indeed! Mrs. Weston, did you ever hear the liks? You and I must positively exert our authority." (p. 200)

In different ways each of the minor characters who stand as a foil to Emma defines herself by her own speech. Harriet Smith by the repetitious, childlike, rough speech and by grammatical mistakes. Jane Fairfax defines herself by her unwillingness to express opinions or to take a stand. Like Emma, nonetheless, Jane Fairfax is aware of despicable qualities in her character even though she is not "rewarded" for her awareness with a husband like Mr. Knighiley. Jane Fairfax is the minor character whose language is clo- 
ser to Emma's. Austen uses Mrs. Elton's speech in order to depict qualities completely distinct from Emma's. Her language is pedansic, shallow, trivial. Her main concern is not to communicate with cthers but to inform them about her "superiority" and her "culture" (especially when she illustrates her arguments with quotations from poems). Her style reveals that she is totally self-centered, the oposite extreme to Emma's magninimity.

\section{NOTES}

1 Graham Hough, "Narrative and Dialogue in Jane Austen," Critical Quarterly, 2 (1970), p. 210.

2 The narrator in Emma will be referred to by the feminine pronoun because the narrative passages are mostly colored by Emma's imangination.

3 Kenneth Moier, Jane Austen's Art of Allusion (Lincoln: University of Nebraska Press, 1968), p. 171.

4 Moler, p. 173.

5 Jane Austen, Emma (New York: W. W. Norton and Company, Inc.), p. 15. All the subsequent references are to this edition and are documented in the body of the paper.

\section{B I B L I O G R A P H Y}

Austen, Jane. Emma. New York: W. W. Norton and Company, 1972.

Hough, Graham. "Narrative and Dialogue in Jane Austen". Critical Quarterly, 12 (1970), pp. 202-229.

McMaster, Juliet, ed. Jane Austen's Achievement. London: The Macmillan Press Ltd., 1976. Moler, Kenneth. Jane Austen's Ant of Allusion. Lincoln: Univrsity of Nebraska Press, 1968.

Page, Norman. "Stylistic Modes in Jane Austen." Ariel E, 2, No. 4 (1971), 45-51.

Pascal, Roy. The Dual Voice. New Jersey: Rowman and Littlefield, 1977. Phillips, K. C. Jane Austen's English. London: André Deutsch, 1970.

\section{RES U M O}

Este trabalho procura ilustrar como Jane Austen segue uma apresentação sistemática de suas personagens em Emma. Primeiro ela apresentação suas personagens em passagens de narrativa, imitando logo após suas maneiras peculiares de expressão em discurso indireto livre, para então introduzi-las dramaticamente no romance. Através da linguagem, Jane Austen procura salientar aspectos da personalidade e da posição social de suas personagens em seus romances. Em Emma particularmente parece evidente que Jane Austen caracteriza Harriet Smith, Jane Fairfax and Mrs. Eiton de tal maneira que a falta de traquejo social ou os defeitos de personalidade destas três personagens são trazidos à luz tão nitidamente (através de suas maneiras pecuiliares de expressāo) que somos imediatamente levados a admirar o traquejo social de Emma c a atenuar os seus defeitos. Além disso, a transformação na iinguagem de Harriet Smith demonstra que apesar de Emma haver falhado em sua tentativa de fazer de Harriet uma heroína, ela não falha inteiramente pois a transformação na linguagem de Harriet indica desenvolvimento e crescimento interior. 